Technical Status Report on the Effect of Phosphate and Aluminum on the Development of Amorphous Phose Separation in Sodium

by

A. D. Cozzi

Westinghouse Savannah River Company

Sovonnoh River Site

Aiken, South Corolino 29808

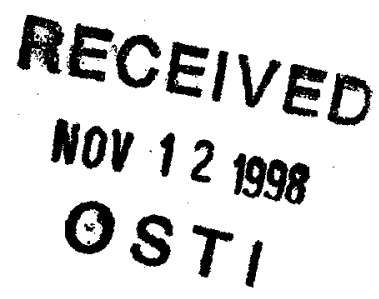

This paper was prepared in connection with work done under the above controct number with the U. S. Department of Energy. By acceptance of this paper, the publisher and/or recipient acknowledges the U. S. Government's right to retain a nonexclusive, royalty-free license in and to any copyright covering this poper, along with the right to reproduce and to outhorize others to reproduce all or part of the copyrighted poper. 
WSRC-TR-98-00327, Revision 0

Keywords: Phase separation, glass, DWPF

Retention: Permanent

September 29, 1998

Roger Gilchrist, Tank Focus Area

Pacific Northwest National Laboratory

Richland, WA 99352

\section{TECHNICAL STATUS REPORT ON THE EFFECT OF PHOSPHATE AND ALUMINUM ON THE DEVELOPMENT OF AMORPHOUS PHASE SEPARATION IN SODIUM BOROSILICATE GLASSES (U)}

In reference to subtask $\mathrm{A}$ of the TFA Optimized Waste Loading Task TTP \#SR1-6-WT-31, a series of laboratory testes were performed to support the goal of opening the high level waste processing window in terms of amorphous phase separation. These tests evaluate the ability of phosphate to induce and aluminum to suppress the formation of glass-inglass phase separation in select borosilicate glass systems.

If you have any questions regarding this report, please contact A.D. Cozzi by phone (803) 725-3250 or E-mail (alex.cozzi@srs.gov).

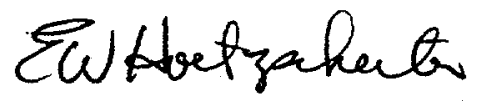

E.W. Holtzscheiter, Manager

SRTC - Immobilization Technology Section 
WSRC-TR-98-00327, Revision 0

TECHNICAL STATUS REPORT ON THE EFFECT OF

PHOSPHATE AND ALUMINUM ON THE DEVELOPMENT OF

AMORPHOUS PHASE SEPARATION IN SODIUM

BOROSILICATE GLASSES (U)

A.D. Cozzi

Westinghouse Savannah River Company

Savannah River Site

Aiken, SC 29808

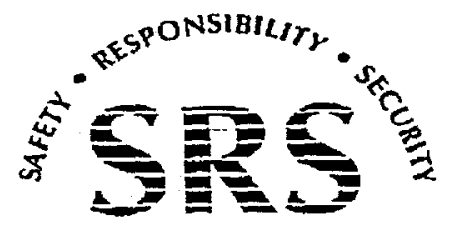

SAVANNAH RIVER SITE

PREPARED FOR THE U.S. DEPARTMENT OF ENERGY UNDER CONTRACT NO. DE-AC09-96SR18500 


\section{DISCLAIMER}

This report was prepared as an account of work sponsored by an agency of the United States Government. Neither the United States Government nor any agency thereof, nor any of their employees, makes any warranty, express or implied, or assumes any legal liability or responsibility for the accuracy, completeness, or usefulness of any information, apparatus, product, or process disclosed, or represents that its use would not infringe privately owned rights. Reference herein to any specific commercial product, process, or service by trade name, trademark, manufacturer, or otherwise does not necessarily constitute or imply its endorsement, recommendation, or favoring by the United States Government or any agency thereof. The views and opinions of authors expressed herein do not necessarily state or reflect those of the United States Government or any agency thereof.

This report has been reproduced directly from the best available copy.

Available to DOE and DOE contractors from the Office of Scientific and Technical Information, P.O. Box 62, Oak Ridge, TN 37831; prices available from (615) 576-8401.

Available to the public from the National Technical Information Service, U.S. Department of Commerce, 5285 Port Royal Road, Springfield, VA 22161. 


\section{DISCLAIMER}

Portions of this document may be illegible in electronic image products. Images are produced from the best available original document. 
WSRC-TR-98-00327, Revision 0

Keywords: Phase separation, glass, DWPF

Retention: Permanent

TECHNICAL STATUS REPORT ON THE EFFECT OF PHOSPHATE AND ALUMINUM ON THE DEVELOPMENT OF AMORPHOUS PHASE SEPARATION IN SODIUM BOROSILICATE GLASSES (U)

A.D. Cozzi 


\section{APPROVALS}

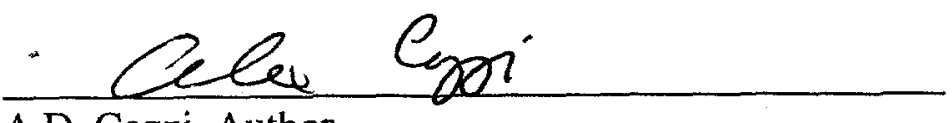

A.D. Cozzi, Author

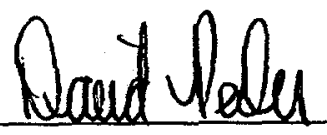

D.K. Peeler, Technical Reviewer

Qawid a. Comby

D.A. Crowley, Manager, Glass Formulation and Melter Technology Ew bloetzahub

E.W. Holtzscheiter, Immobilization Technology
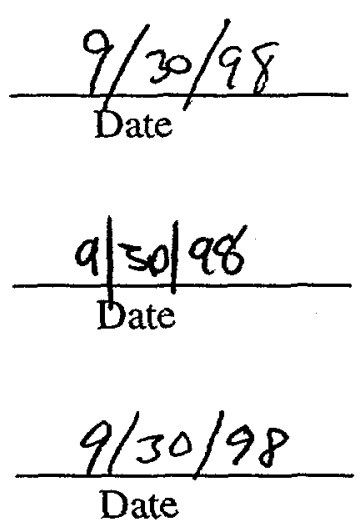

$\frac{9 / 30 / 98}{\text { Date }}$

Westinghouse Savannah River Company

Savannah River Site

Aiken, SC 29808

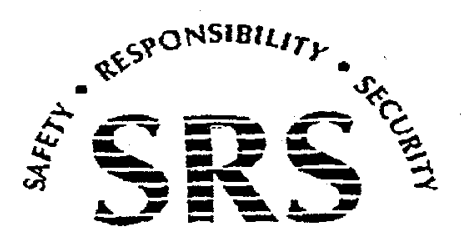




\section{OBJECTIVE}

The objective of the Tank Focus Area "Optimize Waste Loading" task is to enhance the definition of the acceptable processing window for high-level waste vitrification plants. One possible manner in which the acceptable processing window may be enhanced is by reducing the uncertainty of various compositional/property models through a specifically defined experimental plan. A reduction in model uncertainty can reduce limitations on current acceptance constraints and may allow for a larger processing or operational window. Enhanced composition/property model predictions coupled with an increased waste loading may decrease the processing time and waste glass disposal costs (i.e., overall lifecycle costs). One of the compositional/property models currently being evaluated by the Tanks Focus Area is related to the development of amorphous phase separation in multi-component borosilicate glasses.

Described in this report is the current status for evaluating the effect of phosphorus and alumina on both simple sodium borosilicate and high-level waste glasses on the formation of amorphous phase separation. The goal of this subtask is to increase the understanding of the formation of phase separation by adding significant amounts (3-5 wt. \%) of phosphorus and alumina to wellcharacterized glasses. Additional scope includes evaluating the effects of thermal history on the formation of amorphous phase separation and durability of select glasses.

The development of data, understanding, and quantitative description for composition and kinetic effects on the development of amorphous phase separation will continue in FY99. This effort will provide insight into the compositional and thermal effects on phase stability and will lead to a better understanding of the methods used to predict the development of amorphous phase separation in HLW glasses.

\section{BACKGROUND}

Amorphous phase separation is typically defined as the separation, upon cooling, of a homogeneous melt into two or more liquid phases (e.g., glass-in-glass phase separation). Glasses that contain significant amounts of two or more glassformers are likely candidates for phase separation. Borosilicate glasses, although prone to amorphous phase separation, are widely used in the commercial glass industry. Compositions are chosen to either avoid the phase separation region or to take advantage of glass properties such as thermal expansion that are positively influenced by the amorphous phase separation. When an alkali borosilicate undergoes glass-inglass phase separation, two domains differing in composition typically develop. One domain is silica-rich while the other is an alkali-boron enriched phase. These two glass phases can be distributed in three manners. Tomozawa ${ }^{1}$ describes the three structures identified based upon the separation kinetics under which they formed:

Type A: $\quad$ Formed as a result of spinodal decomposition. Both phases are continuous and interconnected. The durability of the glass is governed by the least durable phase.

Type B: $\quad$ Formed by nucleation and growth. The silica-rich phase is dispersed as droplets in a continuous matrix of the alkali-borate phase. The durability of the glass is governed by the continuous phase. 
Type C: Formed by nucleation and growth. The alkali-borate phase is dispersed as droplets in a continuous matrix of the silica-rich phase. The durability of the glass is governed by the continuous phase.

Figure 1 is a schematic representing the subliquidus portion of the phase diagram with the different types of phase separation identified. Multicomponent borosilicate glasses tend to partition in a manner similar to the alkali borosilicates. The addition of phosphate to borosilicate glasses further increases the likelihood for phase separation ${ }^{2}$. Jantzen et al. ${ }^{3}$ and Peeler and $\mathrm{Hrma}^{4}$ provide extensive background on phase separation in general and in multi-component borosilicate waste glasses.

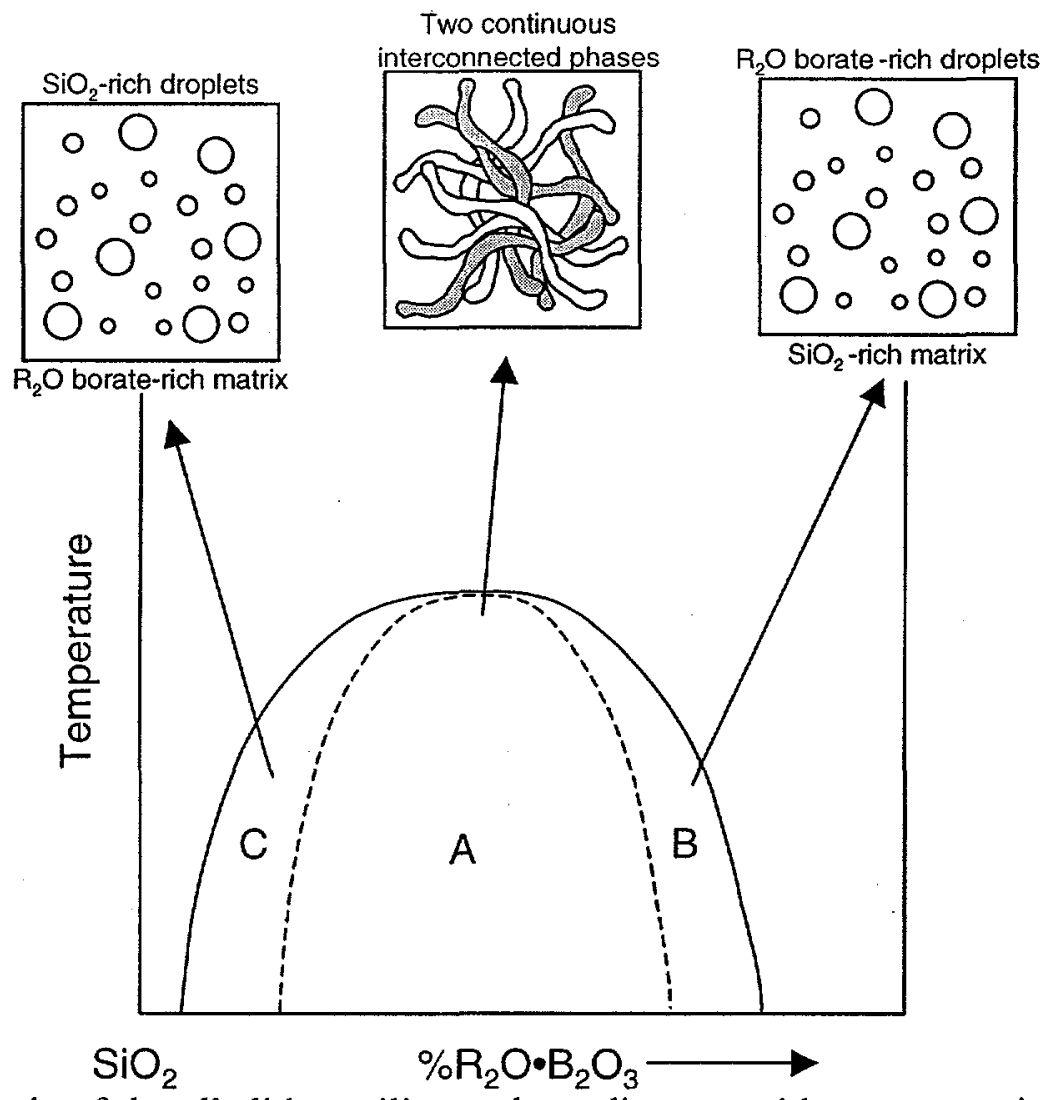

Figure 1. Schematic of the alkali borosilicate phase diagram with representative microstructures for the three possible types of amorphous phase separation.

\section{EXPERIMENTAL}

The experimental task in this study is divided into two parts. Examined in Part 1 are the effects of $\mathrm{Al}_{2} \mathrm{O}_{3}$ and $\mathrm{P}_{2} \mathrm{O}_{5}$ on the development of amorphous phase separation in a set of alkali borosilicate glasses formulated in the sodium borosilicate pseudo-ternary that are either quenched or heat-treated. Heat treatment of a glass is an experimental tool used to develop the phase separated microstructure so that it may be detectable using TEM. However, the use of rigorous heat treatments can bring about phase separation in glasses that would not typically exhibit phase separation when quenched. Used in Part 2 is a known homogeneous glass that represents a 
"sludge poor" DWPF glass (WCP-Purex)". A phase separated frit (Frit 202) will be added incrementally until phase separation is detected via TEM analysis. Since there is no alumina in Frit 202, the frit addition to the glass effectively decreases the alumina content of the finished glass. This permits the evaluation of the effect of alumina on phase separation and glass durability over a compositional continuum. The experimental plan was established to satisfy the technical description of work as defined by Subtask A of TTP \#SR1-6-WT-31.

\section{Sample Selection}

Using the $\mathrm{Na}_{2} \mathrm{O}-\mathrm{B}_{2} \mathrm{O}_{3}-\mathrm{SiO}_{2}$ metastable immiscibility surface determined by Haller et al. ${ }^{5}$, two compositions were chosen to provide a phase separated glass and a homogeneous glass. Figure 2 is the phase diagram with the compositions being evaluated. The phase separated glass (42) was also made with a five weight percent addition of alumina (42A). This was done to evaluate the ability of alumina to suppress amorphous phase separation and increase chemical durability. Volf $^{6}$ reports a two mol percent addition of alumina to a sodium borosilicate glass containing < $12 \mathrm{~mol} \% \mathrm{Na}_{2} \mathrm{O}$ greatly suppresses phase separation an increases glass durability. Glass $42 \mathrm{~A}$ contains $3.2 \mathrm{~mol} \% \mathrm{Al}_{2} \mathrm{O}_{3}$ and $6.3 \mathrm{~mol} \% \mathrm{Na}_{2} \mathrm{O}$. The homogeneous glass composition (12x) was also made with a three (12xP3) and five (12xP5) weight percent addition of phosphorus pentoxide. Phosphate additions to the borosilicate glasses were selected to determine the level at which phosphate induces phase separation in these glasses. Table I lists the compositions used for Part 1 of the study.

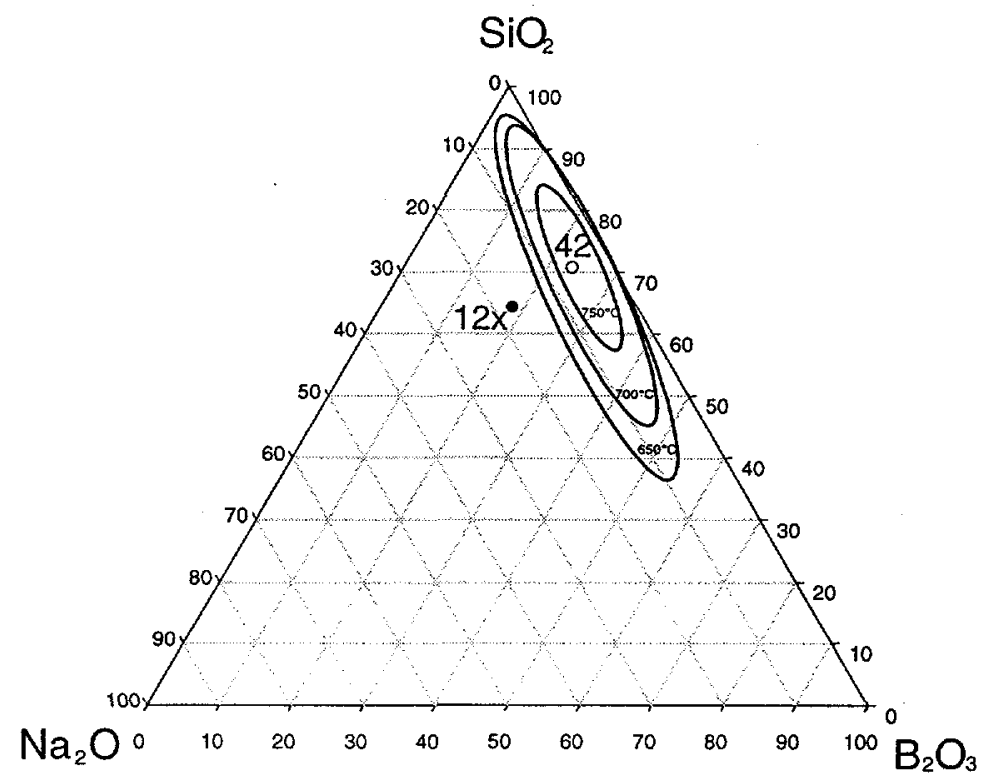

Figure 2. $\mathrm{Na}_{2} \mathrm{O}-\mathrm{B}_{2} \mathrm{O}_{3}-\mathrm{SiO}_{2}$ phase diagram after $\mathrm{Haller}^{5}$ with Part 1 glasses shown, (o - phase separated; • - homogeneous).

\footnotetext{
" DWPF glasses are formulated to utilize the ability of sludge components to produce homogeneous glasses with phase separated frits. WCP-Purex is a DWPF reference glass that represents Frit 202 with a 28 wt. \% sludge loading and $8 \mathrm{wt}$. \% precipitate hydrolysis aqueous.
} 
Table I. Targeted Glass Compositions Used for Part 1 of Study.

\begin{tabular}{|c|c|c|c|c|c|}
\hline & 42 & $42 \mathrm{~A}$ & $12 \mathrm{x}$ & $12 \times \mathrm{P} 3$ & $12 \times \mathrm{P} 5$ \\
\hline $\mathrm{Na}_{2} \mathrm{O}$ & 6.5 & 6.2 & 16.0 & 15.5 & 15.2 \\
\hline $\mathrm{B}_{2} \mathrm{O}_{3}$ & 25.5 & 24.2 & 20.0 & 19.4 & 19.0 \\
\hline $\mathrm{SiO}_{2}$ & 68.0 & 64.6 & 64.0 & 62.1 & 60.8 \\
\hline $\mathrm{Al}_{2} \mathrm{O}_{3}$ & 0 & 5.0 & 0 & 0 & 0 \\
\hline $\mathrm{P}_{2} \mathrm{O}_{5}$ & 0 & 0 & 0 & 3.0 & 5.0 \\
\hline $\mathrm{Sum}$ & 100.0 & 100.0 & 100.0 & 100.0 & 100.0 \\
\hline
\end{tabular}

In Part 2 of the study an evaluation is made as to whether there is a continuum between a homogenous waste glass (WCP-Purex) and a phase separated frit (Frit 202). The composition and properties of both the glass and the frit have been well-characterized ${ }^{3}$. Table II is the targeted glass compositions for the intermediate glasses. Several compositions were chosen at a low loading of Frit 202 based upon the prediction by the current phase separation discriminator used by DWPF that phase separation should occur near the $16 \%$ weight fraction of Frit 202 , figure 3 .

Table II. Expected Glass Compositions Calculated From WCP-Purex and Frit 202.

\begin{tabular}{|c|c|c|c|c|c|c|c|c|}
\hline Oxide & $\begin{array}{l}\text { WCP- } \\
\text { Purex }\end{array}$ & $10-202$ & $20-202$ & $30-202$ & $40-202$ & $60-202$ & $80-202$ & Frit 202 \\
\hline $\mathrm{SiO}_{2}$ & 46.50 & 49.55 & 52.61 & 55.66 & 58.72 & 64.82 & 70.93 & 77.04 \\
\hline $\mathrm{Al}_{2} \mathrm{O}_{3}$ & 2.99 & 2.73 & 2.47 & 2.21 & 1.95 & 1.44 & 0.92 & 0.40 \\
\hline $\mathrm{B}_{2} \mathrm{O}_{3}$ & 10.33 & 10.08 & 9.83 & 9.57 & 9.32 & 8.82 & 8.31 & 7.81 \\
\hline $\mathrm{Na}_{2} \mathrm{O}$ & 12.62 & 11.94 & 11.26 & 10.57 & 9.89 & 8.53 & 7.16 & 5.80 \\
\hline $\mathrm{BaO}$ & 0.20 & 0.18 & 0.16 & 0.14 & 0.12 & 0.08 & 0.04 & -- \\
\hline $\mathrm{CaO}$ & 1.09 & 0.99 & 0.89 & 0.79 & 0.69 & 0.50 & 0.30 & 0.10 \\
\hline $\mathrm{Cr}_{2} \mathrm{O}_{3}$ & 0.15 & 0.14 & 0.12 & 0.11 & 0.09 & 0.06 & 0.03 & -- \\
\hline $\mathrm{CuO}$ & 0.40 & 0.36 & 0.32 & 0.28 & 0.24 & 0.16 & 0.08 & -- \\
\hline $\mathrm{Fe}_{2} \mathrm{O}_{3}$ & 13.25 & 11.93 & 10.60 & 9.28 & 7.95 & 5.30 & 2.65 & -- \\
\hline $\mathrm{MgO}$ & 1.41 & 1.46 & 1.51 & 1.56 & 1.61 & 1.70 & 1.80 & 1.90 \\
\hline $\mathrm{MnO}$ & 1.69 & 1.52 & 1.35 & 1.18 & 1.01 & 0.68 & 0.34 & -- \\
\hline $\mathrm{NiO}$ & 1.19 & 1.07 & 0.95 & 0.83 & 0.71 & 0.48 & 0.24 & -- \\
\hline $\mathrm{TiO}_{2}$ & 0.68 & 0.62 & 0.56 & 0.51 & 0.45 & 0.33 & 0.22 & 0.10 \\
\hline $\mathrm{Li}_{2} \mathrm{O}$ & 3.22 & 3.56 & 3.90 & 4.23 & 4.57 & 5.25 & 5.92 & 6.60 \\
\hline $\mathrm{K}_{2} \mathrm{O}$ & 3.41 & 3.10 & 2.79 & 2.48 & 2.17 & 1.54 & 0.92 & 0.30 \\
\hline $\mathrm{Sum}$ & 99.13 & 99.22 & 99.31 & 99.41 & 99.50 & 99.68 & 99.87 & 100.05 \\
\hline
\end{tabular}

\section{MATERIALS AND METHODS}

Research grade materials ${ }^{\dagger}$ were used to produce the glasses for Part 1 of the study. All of the glasses were melted in platinum crucibles with an alumina lid at the lowest temperature with which the glass could be poured. For the glasses containing $5 \mathrm{wt} . \% \mathrm{P}_{2} \mathrm{O}_{5}$, the melting and heat

\footnotetext{
${ }^{\dagger}$ Fisher $\mathrm{SiO}_{2}$ (S-150-3); Fisher $\mathrm{Al}_{2} \mathrm{O}_{3}$ (A591-500); Spectrum $\mathrm{P}_{2} \mathrm{O}_{5}>98 \%$; Fisher $\mathrm{Na}_{2} \mathrm{CO}_{3}>99.5 \%$; Fisher $\mathrm{H}_{3} \mathrm{BO}_{3}$ $>99.5 \%$.
} 


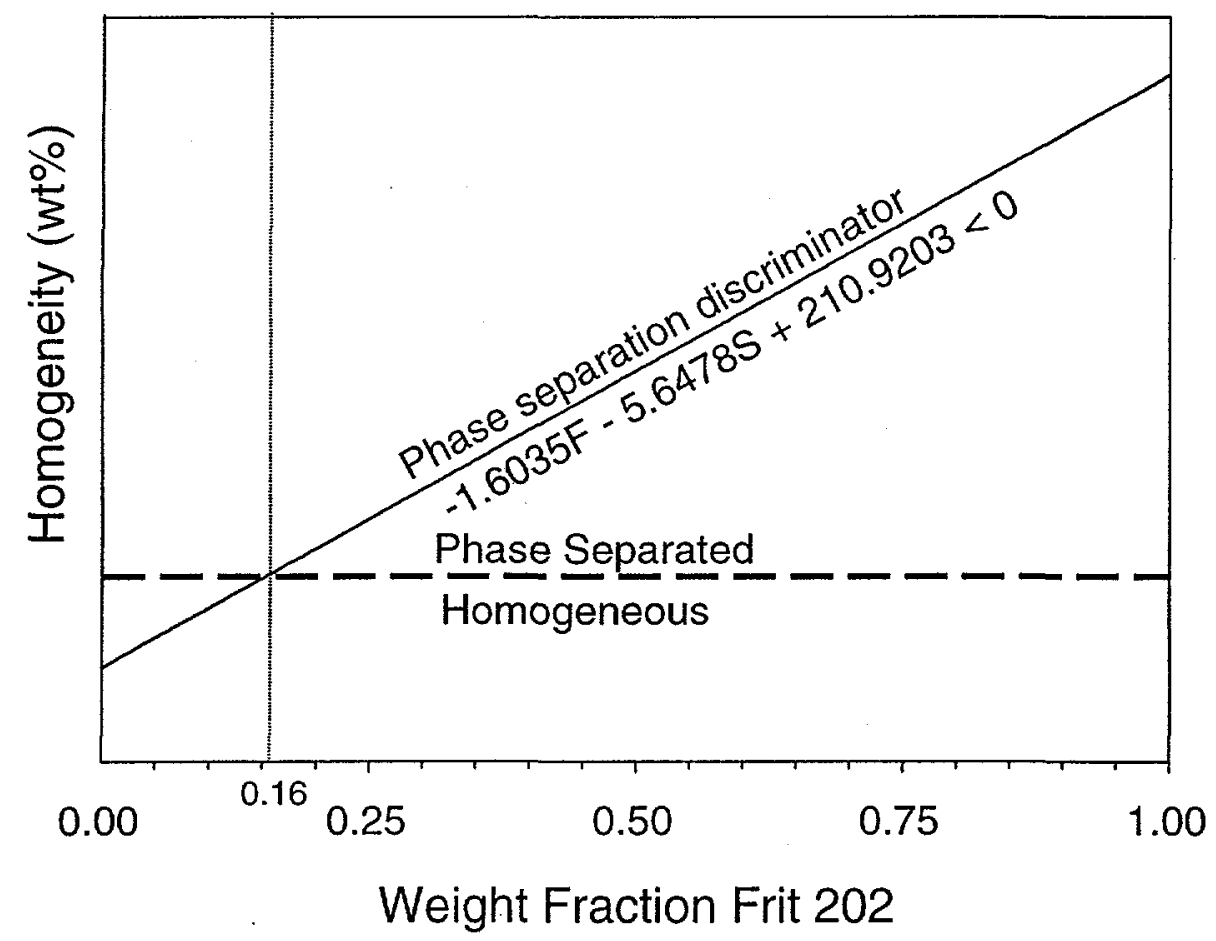

Figure 3. Prediction of amorphous phase separation caused by Frit 202 additions to WCP-Purex glass by the current discriminator, where $\mathrm{F}=$ frit components $=\mathrm{Na}_{2} \mathrm{O}+\mathrm{K}_{2} \mathrm{O}+\mathrm{Li}_{2} \mathrm{O}+$ $\mathrm{Cs}_{2} \mathrm{O}+\mathrm{SiO}_{2}+\mathrm{B}_{2} \mathrm{O}_{3}$ (wt. \%) and $\mathrm{S}=$ sludge components $=\mathrm{Al}_{2} \mathrm{O}_{3}+\mathrm{Fe}_{2} \mathrm{O}_{3}+\mathrm{Nd}_{2} \mathrm{O}_{3}+$ $\mathrm{Ce}_{2} \mathrm{O}_{3}+\mathrm{La}_{2} \mathrm{O}_{3}+\mathrm{Y}_{2} \mathrm{O}_{3}+\mathrm{CaO}+\mathrm{MoO}_{3}$ (wt.\%)

treatment were also performed in a fused quartz crucible. Table III is the processing conditions used for each of the glasses. A portion of each of the glasses produced in Part 1 were thermally treated to simulate the Centerline Canister Cooling (CCC) experienced in the DWPF canisters ${ }^{7}$. This provides a uniform, aggressive thermal treatment for each of the glasses produced and bounds the expected thermal histories of DWPF canister glasses ${ }^{\ddagger}$. The thermal treatment (furnace program segments) each of the Part 1 glasses were subjected to are listed in Table IV.

Table III. Processing Conditions Used for Preparing Part 1 Glasses.

\begin{tabular}{|c|c|c|c|}
\hline Glass & Temperature $\left({ }^{\circ} \mathrm{C}\right)$ & Time $($ Hrs $)$ & Crucible \\
\hline $12 \mathrm{x}$ & 1350 & 4 & Platinum \\
\hline $12 \mathrm{xP}$ & 1350 & 4 & Platinum \\
\hline $12 \mathrm{xP5}$ & 1300 & 4 & Platinum \\
\hline $12 \times \mathrm{P} 5 \mathrm{~S}$ & 1300 & 4 & Fused Quartz \\
\hline 42 & 1250 & 4 & Platinum \\
\hline $42 \mathrm{~A}$ & 1450 & 4 & Platinum \\
\hline
\end{tabular}

\footnotetext{
${ }^{\ddagger}$ Glasses Heat treated are designated by an HT appended on the glass identification.
} 
Table IV. Thermal Treatment Schedule Used in Part 1 to Simulate CCC.

\begin{tabular}{|c|c|c|}
\hline Ramp $\left({ }^{\circ} \mathrm{C} / \mathrm{min}\right)$ & Temperature $\left({ }^{\circ} \mathrm{C}\right)$ & Soak (Hrs) \\
\hline 10 & 1150 & 1 \\
\hline 8 & 926 & 0.1 \\
\hline 1 & 779 & 2.8 \\
\hline 1 & 715 & 3.4 \\
\hline 1 & 598 & 4.2 \\
\hline 1 & 490 & 4.3 \\
\hline 1 & 382 & 7.4 \\
\hline 1 & RT & None \\
\hline
\end{tabular}

All of the glasses produced in Part 1 of the study were subjected to the Product Consistency Test $(\mathrm{PCT})^{\S}$. Compositional analysis was performed on each of the glasses to eliminate the concerns regarding volatility of the boron and sodium and evaluate the feasibility of melting phosphoruscontaining glasses in fused quartz. The glasses also were analyzed using Transmission Electron Microscopy (TEM). X-ray diffraction (XRD) analysis was performed on select glasses that exhibited indications of crystallinity. The use of TEM can provide inconclusive evidence in the determination of phase separation. There is always the possibility of phase separation occurring on a scale not detectable by TEM. Oftentimes, scanning electron microscopy (SEM) and small angle $\mathrm{x}$-ray scattering (SAXS) or small angle neutron scattering (SANS) is used to identify phase separation on either a smaller (SAXS/SANS) or larger (SEM) scale than can be observed using TEM.

The WCP-Purex glass and the Frit 202 were produced and characterized in support of the DWPF startup. The glasses in Part 2 were melted at $1150^{\circ} \mathrm{C}$ in platinum crucibles for four hours and poured onto a steel plate. As with the glasses produced in Part 1, PCT, compositional analysis and TEM analysis were performed on each of the glasses.

\section{RESULTS AND DISCUSSION}

Part 1

Table V is the measured compositions for Part 1 glasses. Comparing these compositions to the targeted compositions in Table I, no significant boron or sodium loss was experienced for the heat treated glasses. Melting in a fused quartz crucible did not contribute noticeable quantities of silica to the composition and may be preferable to platinum for high phosphorus glasses to minimize glass/crucible interactions.

The current DWPF phase separation discriminator predicts that all of the Part 1 glasses should be phase separated for several reasons: 1) $\mathrm{Na}_{2} \mathrm{O}, \mathrm{B}_{2} \mathrm{O}_{3}$ and $\mathrm{SiO}_{2}$ are considered frit components and increase the tendency towards phase separation ${ }^{* *}$; 2) The model is intentionally conservative to

\footnotetext{
$\$$ ASTM C 1285-94 Standard Test Methods for Determining Chemical Durability of Nuclear Waste Glasses: The Product Consistency Test (PCT).

** The current DWPF phase separation discriminator separates the glass composition into frit components and sludge components. Glasses must contain $>12.5$ wt. \% sludge components.
} 
ensure that phase separated glasses could not be produced in the DWPF; and 3). Phosphorus does not participate in the current model. Since these glasses are predicted to be phase separated, the durability model cannot offer a glass durability ${ }^{\dagger \dagger}$. Table VI is the normalized boron release and the TEM observations for each of the Part 1 glasses.

Table V. Normalized Measured Compositions for Part 1 Glasses.

a) Phase Separated Glasses and Alumina Additions.

\begin{tabular}{|c|c|c|c|c|}
\hline Oxide & 42 & $42-\mathrm{HT}$ & $42 \mathrm{~A}$ & $42 \mathrm{~A}-\mathrm{HT}$ \\
\hline $\mathrm{Al}_{2} \mathrm{O}_{3}$ & 0.00 & 0.00 & 4.69 & 4.85 \\
\hline $\mathrm{B}_{2} \mathrm{O}_{3}$ & 23.39 & 24.83 & 24.84 & 23.73 \\
\hline $\mathrm{Na}_{2} \mathrm{O}$ & 5.83 & 6.02 & 5.85 & 6.05 \\
\hline $\mathrm{SiO}_{2}$ & 70.78 & 69.15 & 64.62 & 65.38 \\
\hline $\mathrm{Sum}$ & 100 & 100 & 100 & 100 \\
\hline
\end{tabular}

b) Homogeneous Glasses and Phosphate Additions.

\begin{tabular}{|c|c|c|c|c|c|c|c|c|}
\hline Oxide & $12 \times$ & $12 \times-\mathrm{HT}$ & $12 \times \mathrm{P}$ & $\begin{array}{c}12 \times \mathrm{P} \\
\mathrm{HT}\end{array}$ & $\begin{array}{c}12 \times \mathrm{P} 5 \\
(\mathrm{Pt})\end{array}$ & $\begin{array}{c}12 \times \mathrm{P} 5 \\
\mathrm{HT}(\mathrm{Pt})\end{array}$ & $\begin{array}{c}12 \times \mathrm{P} 5 \\
(\mathrm{Qtz})\end{array}$ & $\begin{array}{c}12 \times \mathrm{P} 5 \\
\text { HT }(\mathrm{Qtz})\end{array}$ \\
\hline $\mathrm{B}_{2} \mathrm{O}_{3}$ & 18.26 & 18.11 & 18.11 & 18.75 & 18.88 & 19.49 & 17.62 & 18.18 \\
\hline $\mathrm{Na}_{2} \mathrm{O}$ & 17.36 & 17.42 & 16.42 & 17.66 & 16.49 & 15.98 & 16.21 & 16.05 \\
\hline $\mathrm{P}_{2} \mathrm{O}_{5}$ & 0.00 & 0.00 & 2.87 & 2.68 & 4.99 & 4.83 & 5.05 & 4.94 \\
\hline $\mathrm{SiO}_{2}$ & 64.38 & 62.60 & 62.60 & 60.91 & 59.64 & 59.70 & 61.12 & 60.84 \\
\hline $\mathrm{Sum}$ & 100 & 100 & 100 & 100 & 100 & 100 & 100 & 100 \\
\hline
\end{tabular}

Table VI. Normalized Boron Release Calculated from the PCT Test and Phase Separation Observations for Part 1 Glasses.

\begin{tabular}{|c|c|c|c|}
\hline Glass & NL $[\mathrm{B}]$ & $\log \mathrm{NL}[\mathrm{B}]$ & $\begin{array}{c}\text { Phase } \\
\text { Separation }\end{array}$ \\
\hline & $\mathrm{g} / \mathrm{L}$ & $\mathrm{G} / \mathrm{L}$ & TEM \\
\hline 42 & 22.17 & 1.35 & Yes \\
\hline $42 \mathrm{HT}$ & 64.23 & 1.81 & Yes \\
\hline $42 \mathrm{~A}$ & 40.91 & 1.61 & No \\
\hline $42 \mathrm{AHT}$ & 55.12 & 1.74 & No \\
\hline $12 \mathrm{x}$ & 11.98 & 1.08 & No \\
\hline $12 \times \mathrm{HT}$ & 14.10 & 1.15 & No \\
\hline $12 \times \mathrm{P} 3$ & 29.60 & 1.47 & Yes \\
\hline $12 \times P 3 \mathrm{HT}$ & 33.29 & 1.52 & Yes \\
\hline $12 \times P 5$ & 27.44 & 1.44 & Yes \\
\hline $12 \times P 5 H T$ & 29.10 & 1.46 & Yes \\
\hline NL[B] - normalized boron release &
\end{tabular}

In the two glasses purposefully made to be phase separated (42 and 42-HT), the extent of the phase separation brought about by the heat treatment significantly decreased the glass durability $\left(\mathrm{NL}[\mathrm{B}]_{42}=22.17, \mathrm{NL}[\mathrm{B}]_{42 \mathrm{HT}}=64.23\right)$. Figure 4 shows the TEM photographs of the two glasses

it A durability for phase separated glasses can be calculated but there is little statistical confidence in the accuracy.

\# Values are corrected to blanks and normalized for the measured boron content of the glass. ARM-1 results were control charted to historical data to ensure reliability and consistency of method. 


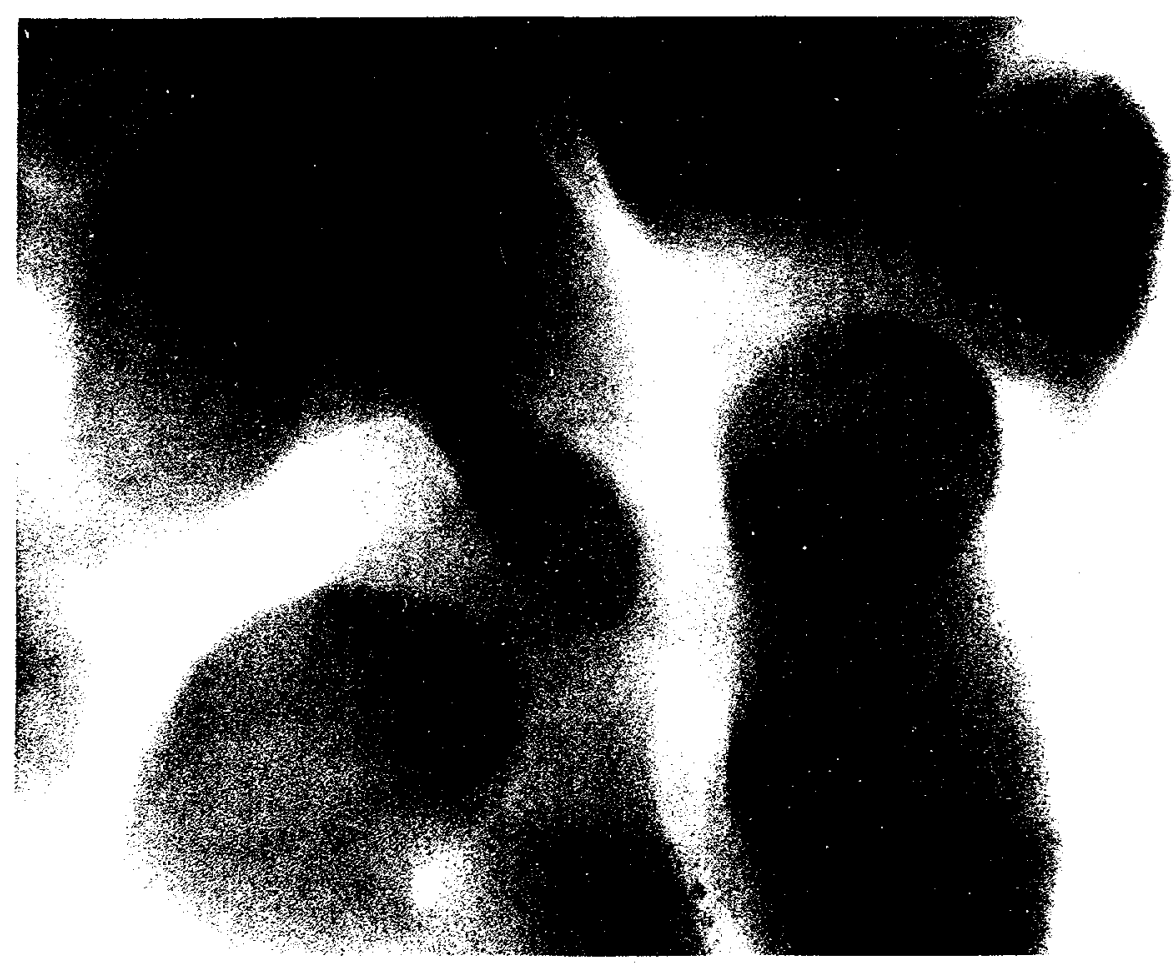

Figure 4a) TEM of glass 42 quenched $(273,000 \mathrm{x})$.

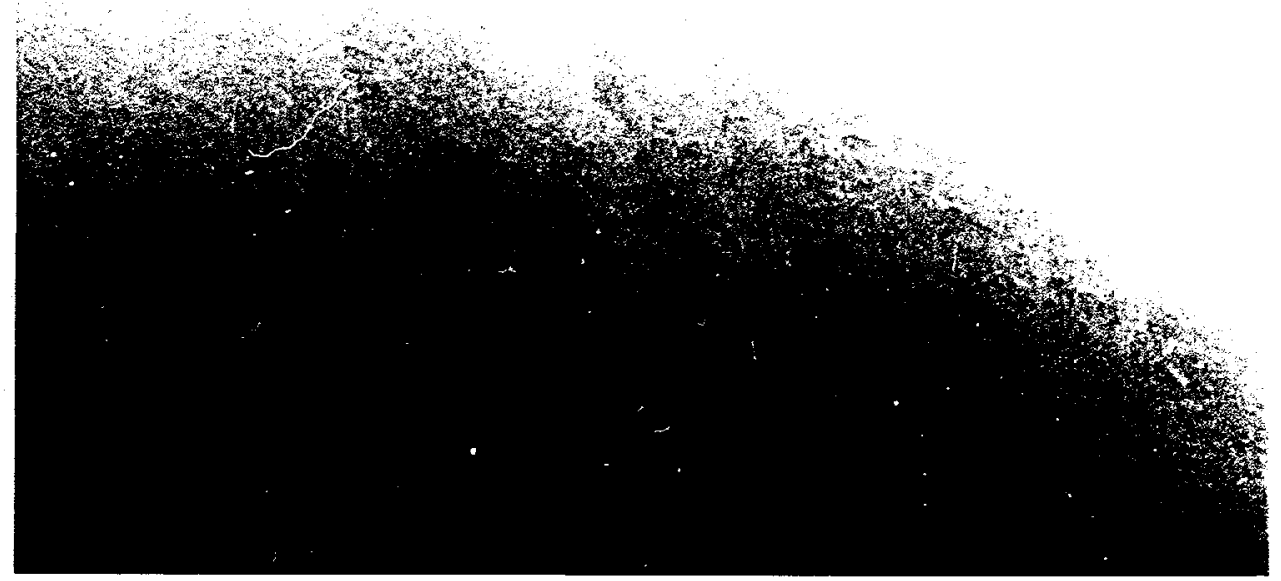

Figure 4b) TEM of glass 42 heat treated using the CCC schedule $(160,000 x)$. 
before and after heat treatment. Whereas the phase separation in the quenched glass is barely detectable using TEM, the heat-treated glass became opalescent and could be easily be characterized as phase separated. This is an indication that amorphous phase separation occurs on several size scales and cannot be definitively ruled out by any one analytical method. When the 42 and $42 \mathrm{~A}$ glasses were reproduced with a five weight percent addition of alumina, the durability of the quenched glass (42A) decreased. However, heat treatment of this glass (42A$\mathrm{HT}$ ) reduced the glass durability only slightly. In addition to Volf ${ }^{6}$, Vienna et al. ${ }^{8}$ showed that in some glasses determined to be homogeneous, a small alumina addition can significantly increase the glass durability. Plotting the compositions of the 42 and $42 \mathrm{~A}$ glasses on the $\mathrm{Na}_{2} \mathrm{O}-\mathrm{B}_{2} \mathrm{O}_{3}-\mathrm{SiO}_{2}$ ternary phase diagram, they fall into the region of phase separation where interconnected phases are expected. This correlates to Type A amorphous phase separation from spinodal decomposition. This may explain the low durability of the glasses in the presence of five weight percent alumina. The appearance of phase separation cannot be confirmed from the TEM photos of the quenched and heat-treated glasses, figure 5. It is possible that phase separation may exist on a scale not detectable using TEM but large enough to influence glass durability.

The second glass composition (12x) chosen to be homogeneous, was heat treated to ensure the glass remained homogeneous. Heat treatment did not significantly decrease the glass durability and phase separation was not detectable using TEM. Additions of three and five weight percent phosphorus induced phase separation in the quenched glasses as well as the heat-treated glasses, figure 6. Electron Diffraction Spectroscopy (EDS) of the two phases suggests that the droplet phase is enriched in oxygen. This is consistent with this glass composition falling near the expected region of silica-rich droplets in a sodium borate rich matrix. X-ray diffraction analyses of the heat-treated glasses reveal the formation of crystalline silica. Figure 7 is the XRD patterns of the three weight percent phosphorus glass before and after heat treatment. Phase separation acting as a precursor to crystallization was also reported by Peeler et al. ${ }^{4}$ Phosphorus additions of three and five weight percent decreased the durability of the glasses. No noticeable difference in durability was detected between the glasses with three and five weight percent phosphorus. In addition, the durability of the two phosphorus-containing glasses was not notably affected by heat treatment. In Part 1 of this study, the current phase separation discriminator predicted all of the Part 1 glasses to be phase separated. Evaluation of all of the Part 1 glasses suggests that on the scale detectable by TEM, glasses $12 \mathrm{x}$ and $42 \mathrm{~A}$ were homogeneous. Glass $12 \mathrm{x}$ was formulated in a known homogeneous glass-forming region and evaluation of a heat-treated glass $42 \mathrm{~A}$ was inconclusive regarding phase separation. 


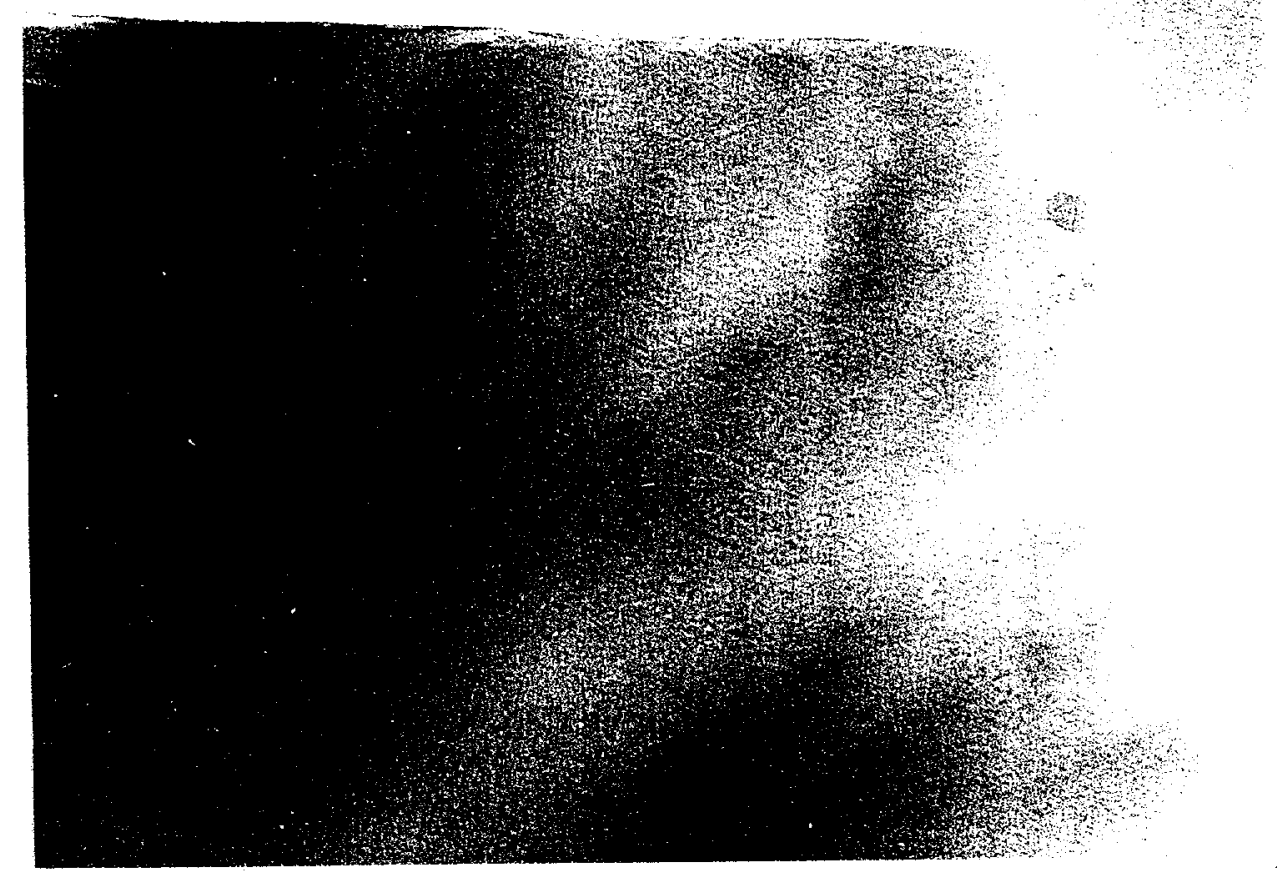

Figure 5a) TEM of glass 42A quenched $(270,000 \mathrm{x})$.

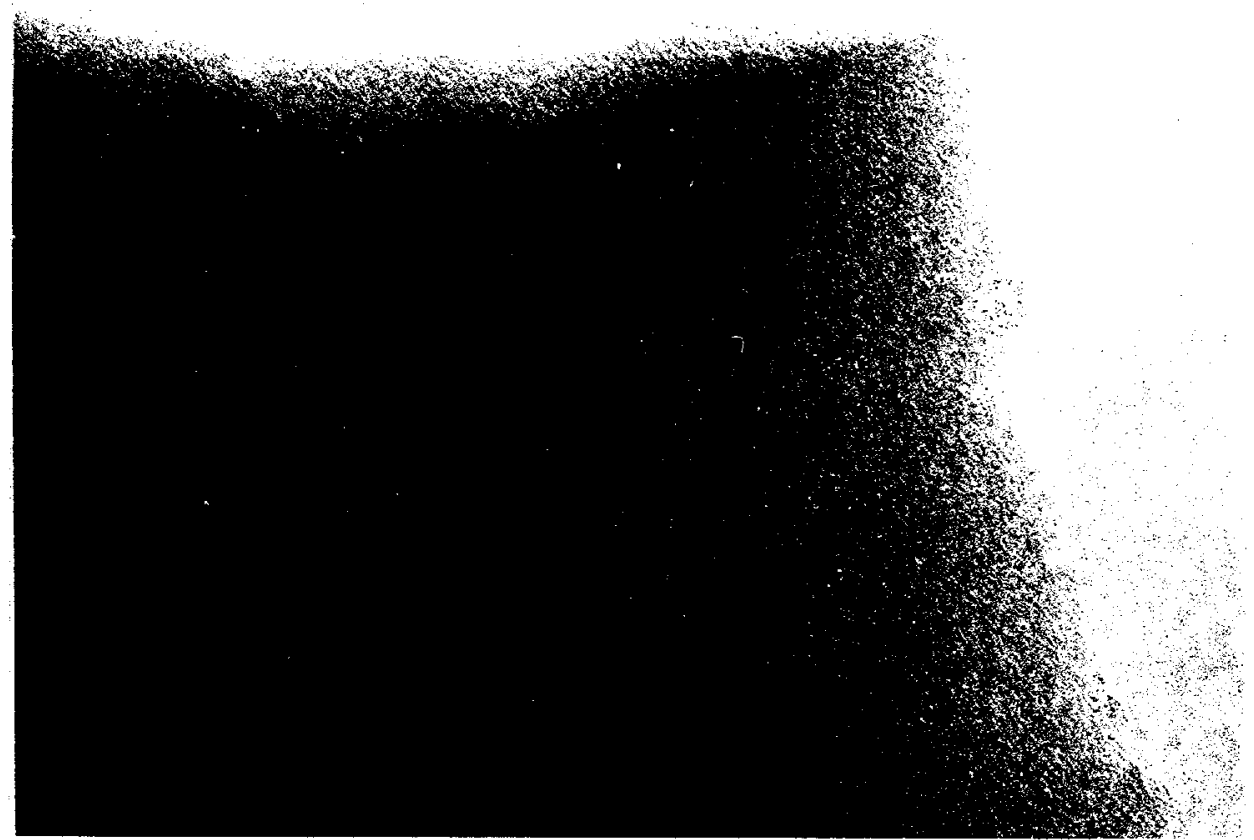

Figure $5 b) \quad$ TEM of glass $42 \mathrm{~A}$ heat treated using the CCC schedule $(360,000 \mathrm{x})$. 


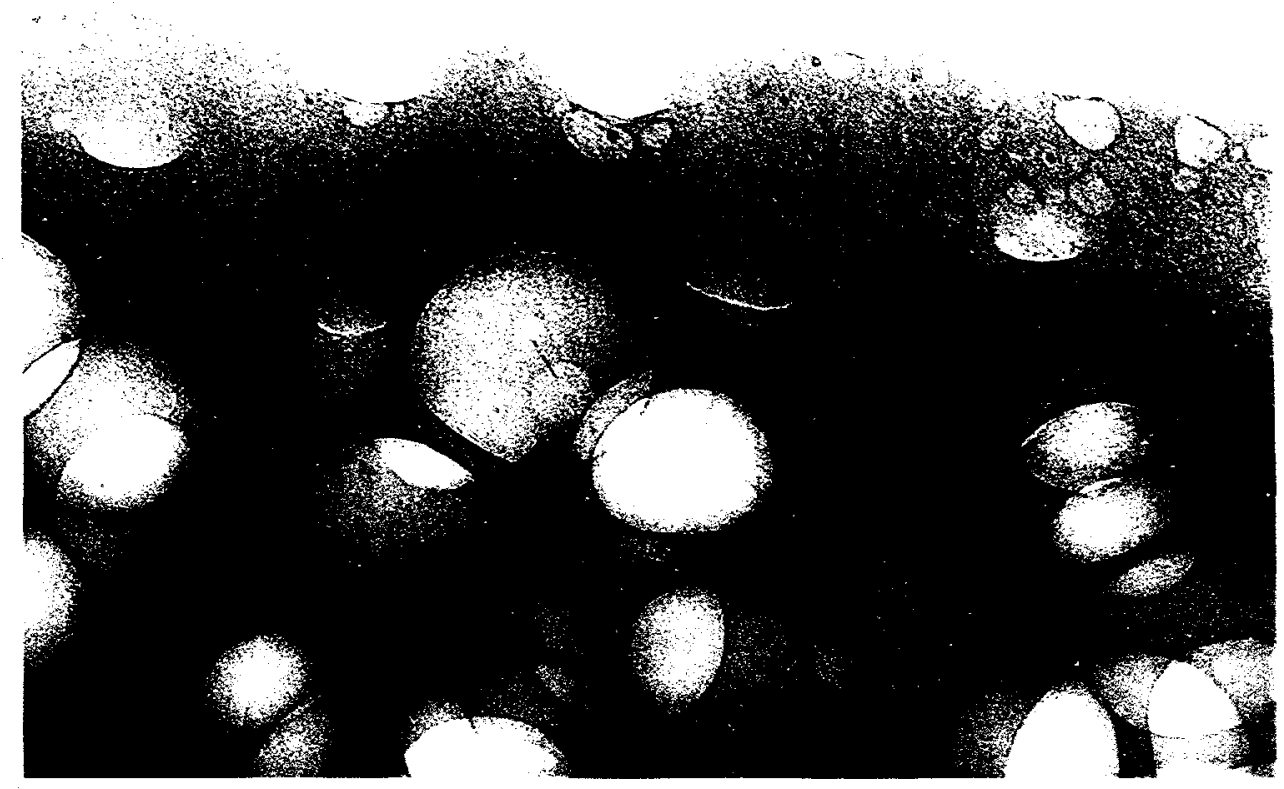

Figure 6a) TEM of glass $12 x P 3$ quenched $(200,000 x)$.

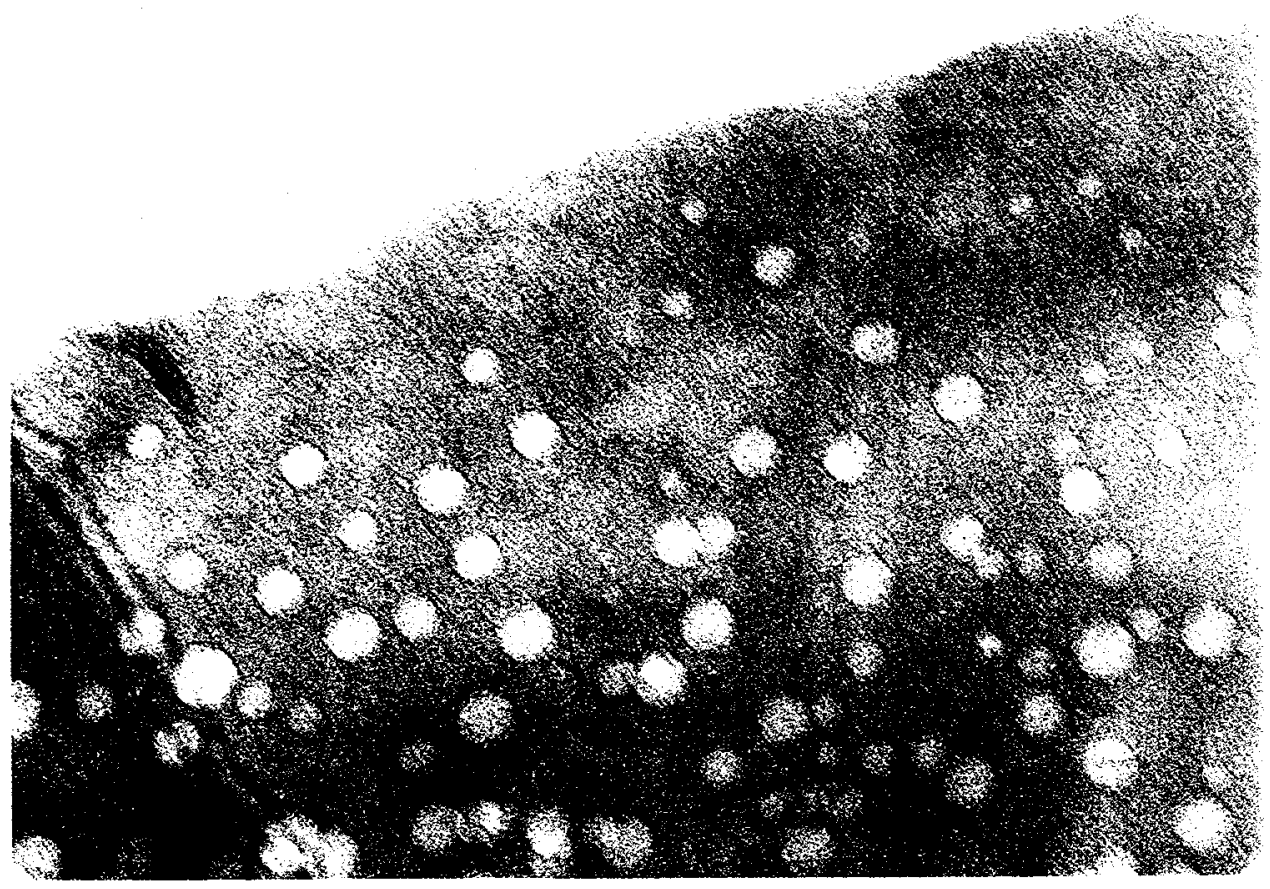

Figure $6 \mathrm{~b}) \quad$ TEM of glass $12 \mathrm{xP} 3$ heat treated using the CCC schedule $(187,000 \mathrm{x})$. 


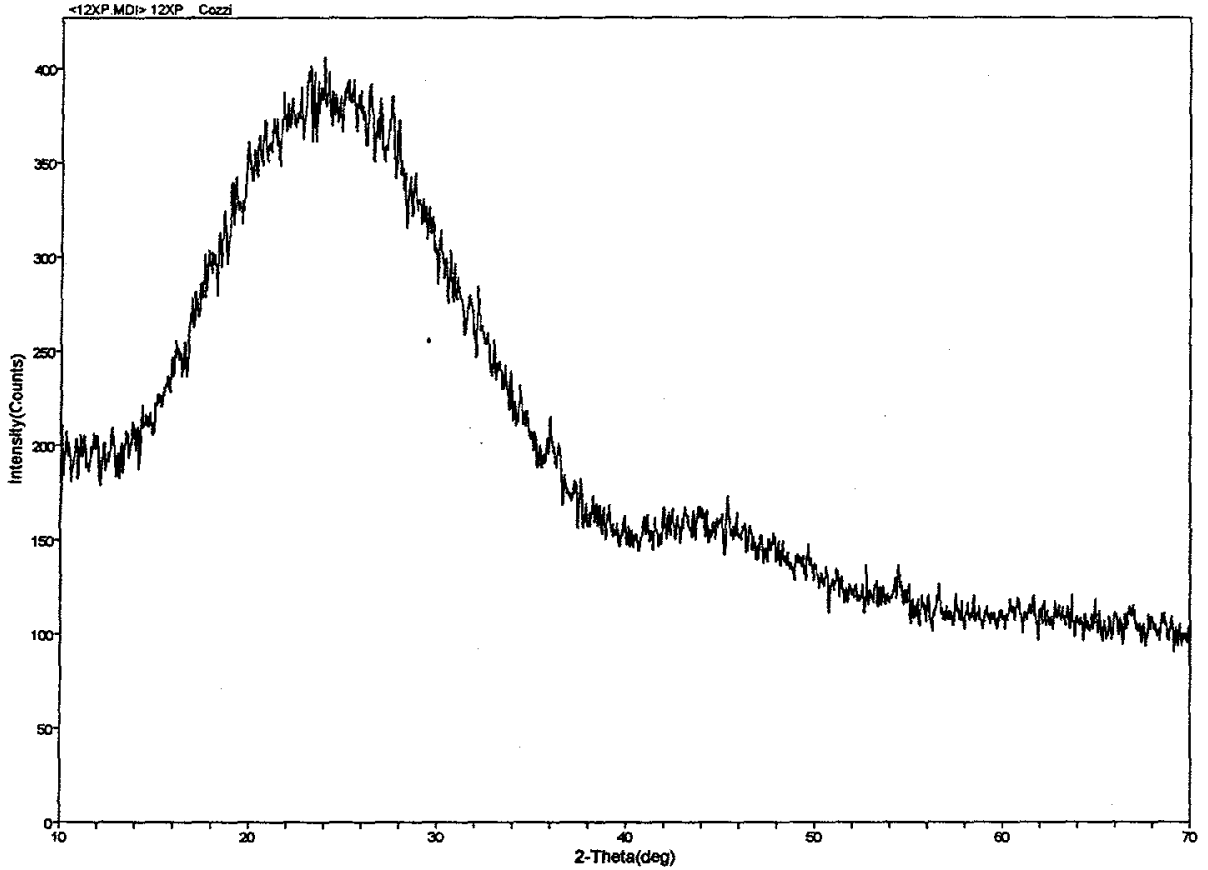

Figure $7 \mathrm{a}) \quad \mathrm{XRD}$ of glass $12 \times \mathrm{P} 3$ quenched.

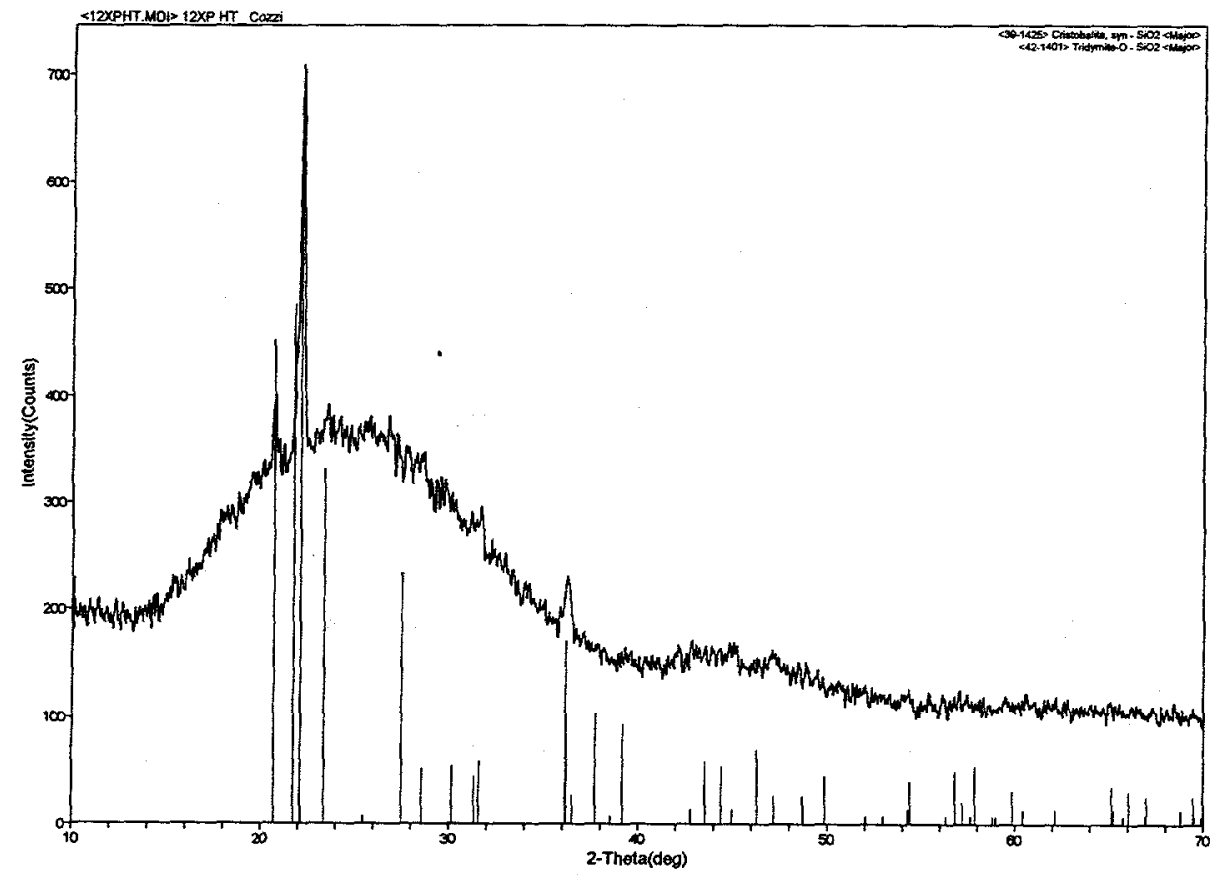

Figure $7 b) \quad \mathrm{XRD}$ of glass $12 \times \mathrm{P} 3$ heat treated using the $\mathrm{CCC}$ schedule. 


\section{Part 2}

Table VII is the normalized measured compositions for the Part 2 glasses. The measured compositions compare favorably with the expected compositions from Table II.

Table VII. Normalized Measured Compositions of Part 2 Glasses.

\begin{tabular}{|c|c|r|r|r|r|r|r|r|}
\hline Oxide & WCP-Purex & $\mathbf{1 0 - 2 0 2}$ & $\mathbf{2 0 - 2 0 2}$ & $\mathbf{3 0 - 2 0 2}$ & $\mathbf{4 0 - 2 0 2}$ & $\mathbf{6 0 - 2 0 2}$ & $\mathbf{8 0 - 2 0 2}$ & frit 202 \\
\hline $\mathrm{Al}_{2} \mathrm{O}_{3}$ & 3.02 & 2.81 & 2.59 & 2.39 & 1.98 & 1.32 & 0.89 & 0.40 \\
\hline $\mathrm{B}_{2} \mathrm{O}_{3}$ & 10.43 & 9.19 & 10.43 & 10.33 & 8.96 & 8.83 & 8.07 & 7.81 \\
\hline $\mathrm{BaO}$ & 0.20 & 0.23 & 0.22 & 0.21 & 0.12 & 0.08 & 0.05 & 0.00 \\
\hline $\mathrm{CaO}$ & 1.10 & 1.06 & 1.03 & 0.91 & 0.72 & 0.48 & 0.30 & 0.10 \\
\hline $\mathrm{Cr}_{2} \mathrm{O}_{3}$ & 0.15 & 0.33 & 0.32 & 0.31 & 0.26 & 0.26 & 0.24 & 0.00 \\
\hline $\mathrm{CuO}$ & 0.40 & 0.38 & 0.38 & 0.32 & 0.25 & 0.15 & 0.08 & 0.00 \\
\hline $\mathrm{Fe}_{2} \mathrm{O}_{3}$ & 13.38 & 12.39 & 11.97 & 11.04 & 8.14 & 5.42 & 3.14 & 0.00 \\
\hline $\mathrm{K}_{2} \mathrm{O}$ & 3.44 & 3.06 & 2.86 & 2.63 & 2.06 & 1.51 & 0.87 & 0.30 \\
\hline $\mathrm{Li}_{2} \mathrm{O}$ & 3.25 & 3.56 & 3.41 & 3.71 & 4.48 & 5.26 & 5.70 & 6.60 \\
\hline $\mathrm{MgO}_{2 n O}$ & 1.42 & 1.47 & 1.51 & 1.56 & 1.56 & 1.61 & 1.80 & 1.90 \\
\hline $\mathrm{MnO}_{2}$ & 1.71 & 1.79 & 1.72 & 1.60 & 1.21 & 0.76 & 0.40 & 0.00 \\
\hline $\mathrm{Na}_{2} \mathrm{O}$ & 12.74 & 11.98 & 12.28 & 10.94 & 10.02 & 8.54 & 7.03 & 5.80 \\
\hline $\mathrm{NiO}^{\mathrm{SiO}}$ & 1.20 & 1.16 & 1.15 & 1.01 & 0.81 & 0.51 & 0.30 & 0.00 \\
\hline $\mathrm{TiO}_{2}$ & 46.96 & 49.96 & 49.51 & 52.47 & 58.85 & 64.92 & 70.89 & 77.00 \\
\hline $\mathrm{Sum}$ & 9.59 & 0.64 & 0.63 & 0.58 & 0.59 & 0.35 & 0.25 & 0.10 \\
\hline
\end{tabular}

Shaded cells represent calculated values used to replace a poor dissolution. All other elements agree with expected compositions and were obtained by a lithium metaborate fusion. $\mathrm{Li} 2 \mathrm{O}$ and $\mathrm{B} 2 \mathrm{O} 3$ are obtained from a microwave digestion.

The current DWPF phase separation discriminator was applied to all of the above glasses. WCPPurex, 10-202 and 20-202 were predicted to be homogeneous and the remaining glasses were predicted to be phase separated. The DWPF durability model was applied to the glasses predicted to be homogeneous. Table VIII is the predicted and observed (TEM) state of the glass as well as the predicted and measured boron release for each of the glasses. The double line delineates the glasses predicted to be homogeneous from the glasses predicted to be phase separated. The triple line delineates the glasses that are measured to be statistically more durable than the Environmental Assessment (EA) glass from those measured to be less durable. The predicted boron release for the two homogeneous (predicted) glasses made in this study agreed well with the measured boron release. As with the Part 1 glasses, the phase separation discriminator was conservative in predicting phase separation in glasses analyzed using TEM. Whereas these glasses were deemed homogeneous, there is a phase separation may exist on a scale not detectable by TEM. Figure 8 is representative micrographs of several of the glasses determined to be homogeneous via TEM analysis. 
Westinghouse Savannah River Company

Savannah River Technology Center

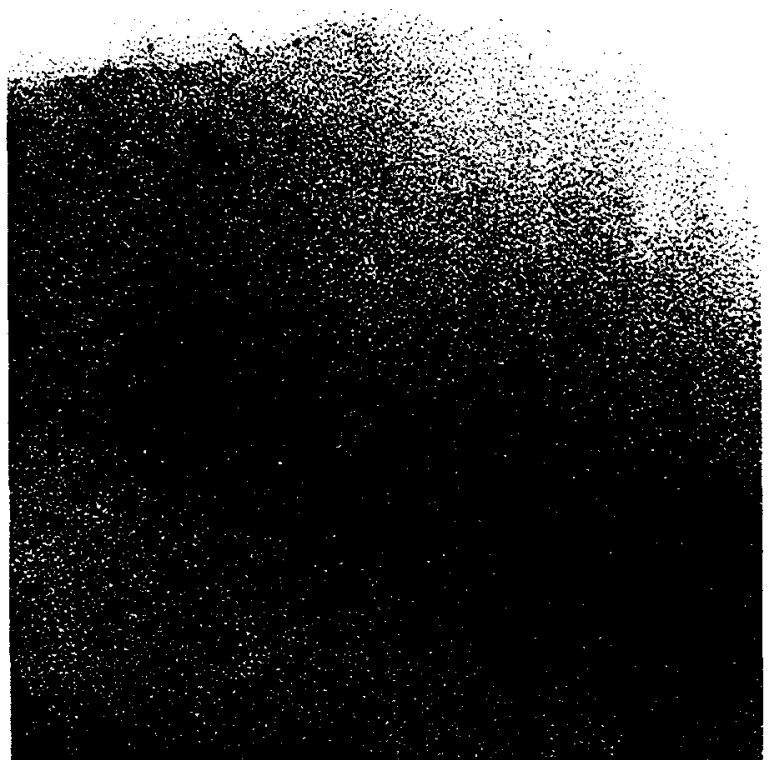

Figure 8a) TEM of glass 10-202 (270,000x).

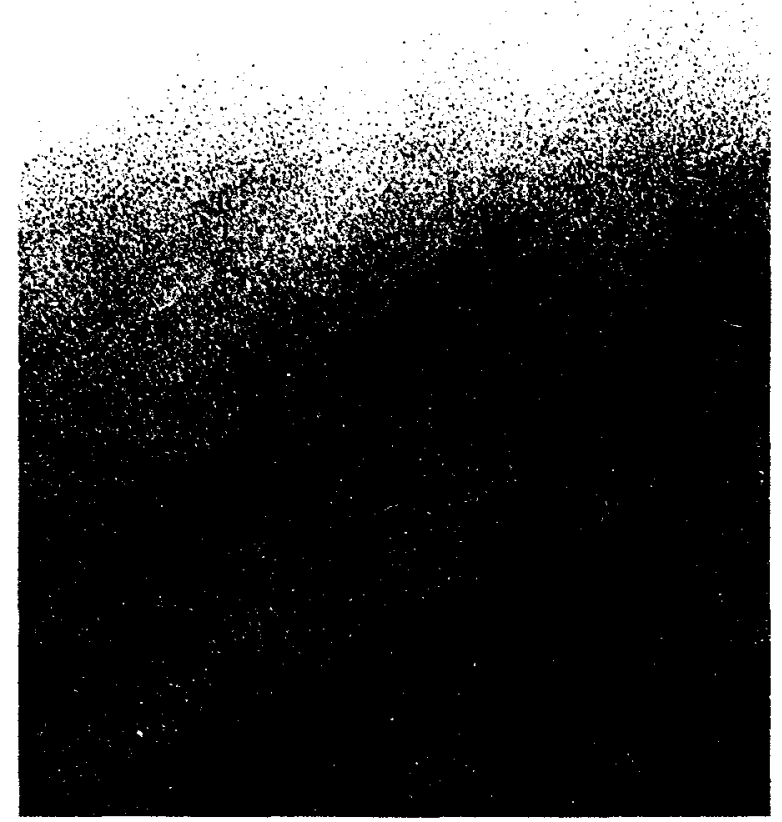

Figure $8 c)$ TEM of glass $40-202(270,000 x)$.
September 30, 1998

WSRC-TR-98-00327, Revision 0

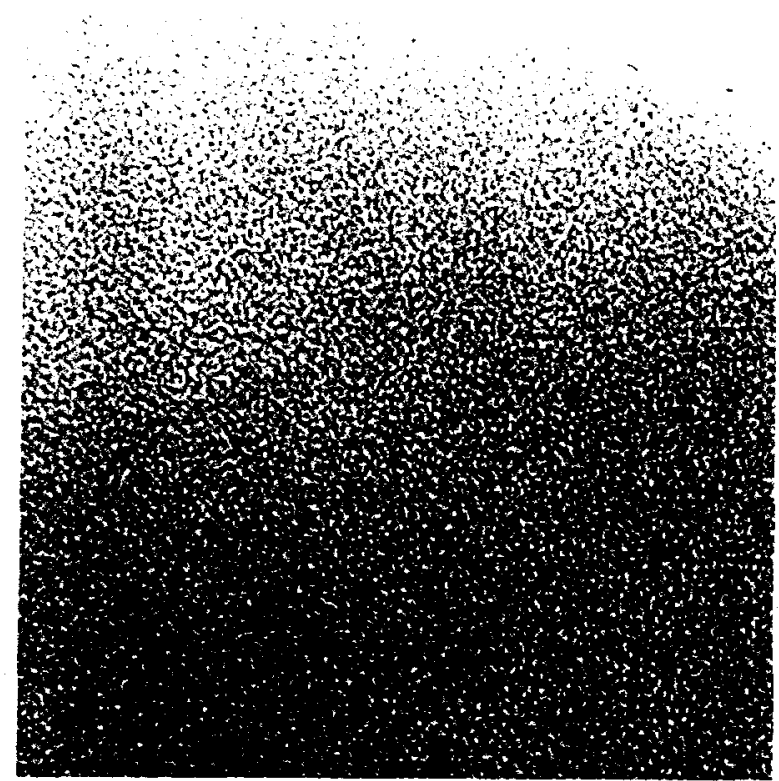

Figure $8 b)$ TEM of glass $30-202(280,000 x)$.

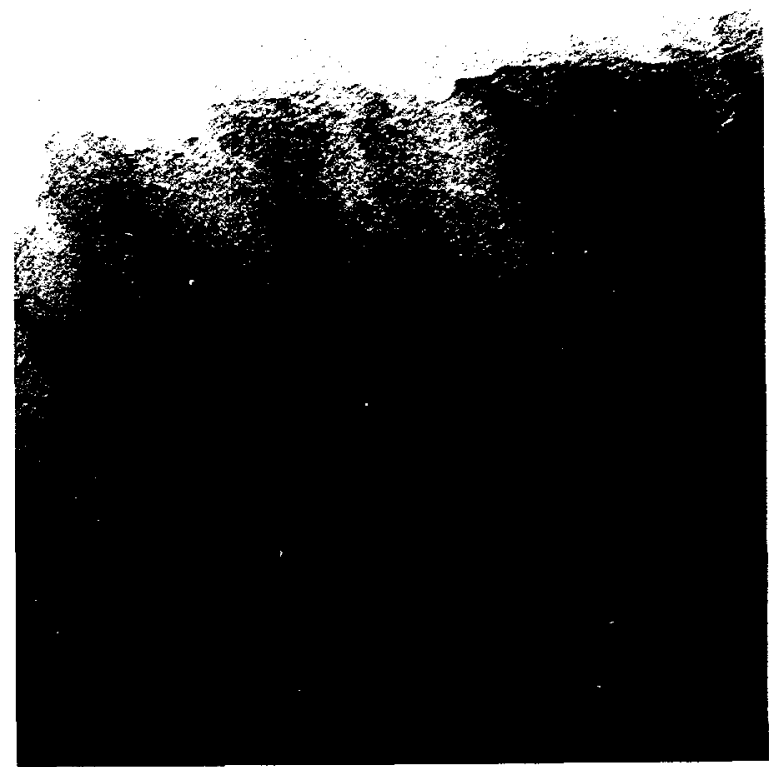

Figure 8d) TEM of glass $80-202(270,000 x)$. 
In Figure 9 the Part 2 glasses are plotted on the $\mathrm{R}_{2} \mathrm{O}-\mathrm{B}_{2} \mathrm{O}_{3}-\mathrm{SiO}_{2}+\mathrm{Al}_{2} \mathrm{O}_{3}$ phase diagram. The WCP-Purex glass and those with small $(<30 \mathrm{wt} \%$ ) Frit 202 additions lay in the region of homogeneous waste glasses. With increased Frit 202 additions the composition moves out of the acceptable waste glass region into a glass-forming region that may not produce durable glasses. Since glasses with $>20$ wt. \% additional Frit 202 added were predicted by the phase separation discriminator to be phase separated, there is little statistical confidence in the predicted durability. When the Frit 202 addition reaches 80 percent, the homogeneous nature of the glass is not assured.

Table VIII. Predicted and Measured Properties for the Part 2 Glasses, WCP-Purex and Frit 202.

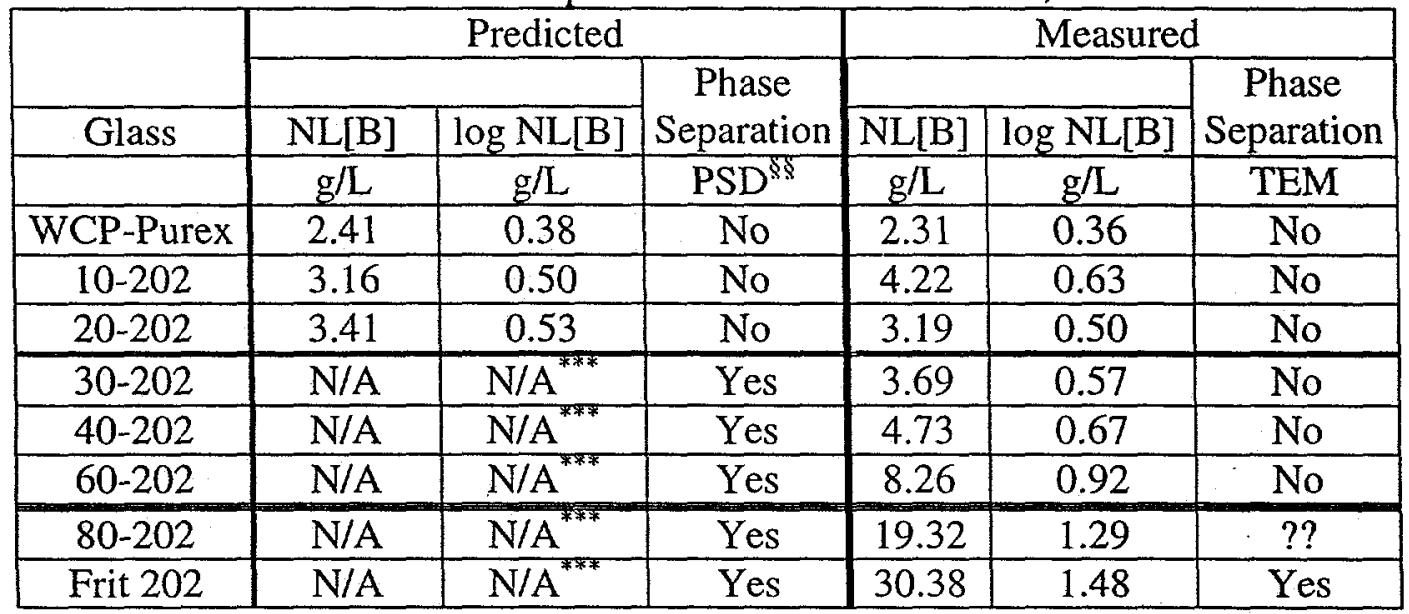

Figure 10 is the normalized boron release as a function of Frit 202 additions. The glasses up to and including $60 \mathrm{wt}$. \% Frit 202 were significantly more durable than EA glass. Several glasses were made that fall in the middle region of the figure that are acceptable from a durability standpoint but are flagged by the current discriminator as phase separated. The trend in boron release from the WCP-Purex glass to the Frit 202 glass suggests that the durability falls off gradually as the glass moves towards a phase separated composition. This trend is more favorable for processing acceptable glass than the possibility of an abrupt decrease in glass durability with the onset of phase separation. When the normalized boron release is plotted against the calculated free energy of hydration, all but two of the Part 2 glasses are within the confidence interval surrounding the predicted boron release, figure 11 . This indicates that a reasonable durability prediction can be made on several of the glasses predicted to be phase separated but deemed homogeneous on the scale of the TEM. Figure 12 plots the boron release as a function of alumina. As in reference fourteen, there is a marked affect of alumina additions on the glass durability.

\footnotetext{
$\$ \$$ PSD - Phase Separation Discriminator

${ }^{* * *}$ Statistically confident durability predictions cannot be made on glasses predicted by the PSD to be phase separated.
} 


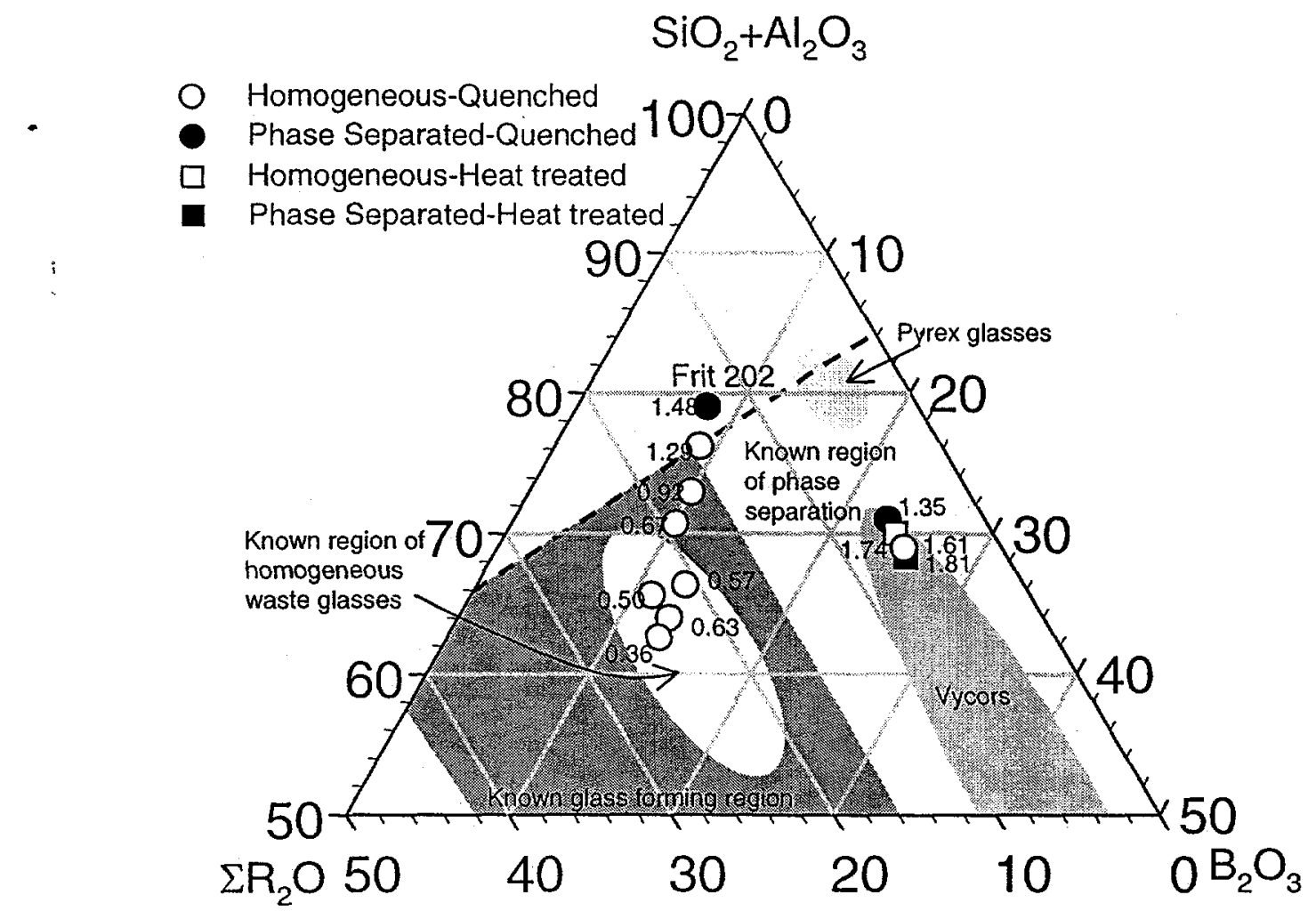

Figure 9. Part 2 glasses (WCP-Purex + Frit 202) and Series 42 glasses normalized and plotted on the $\Sigma \mathrm{R}_{2} \mathrm{O}-\mathrm{B}_{2} \mathrm{O}_{3}-\mathrm{SiO}_{2}+\mathrm{Al}_{2} \mathrm{O}_{3}$ ternary phase diagram. Numbers adjacent to symbols indicate normalized boron release, NL[B].

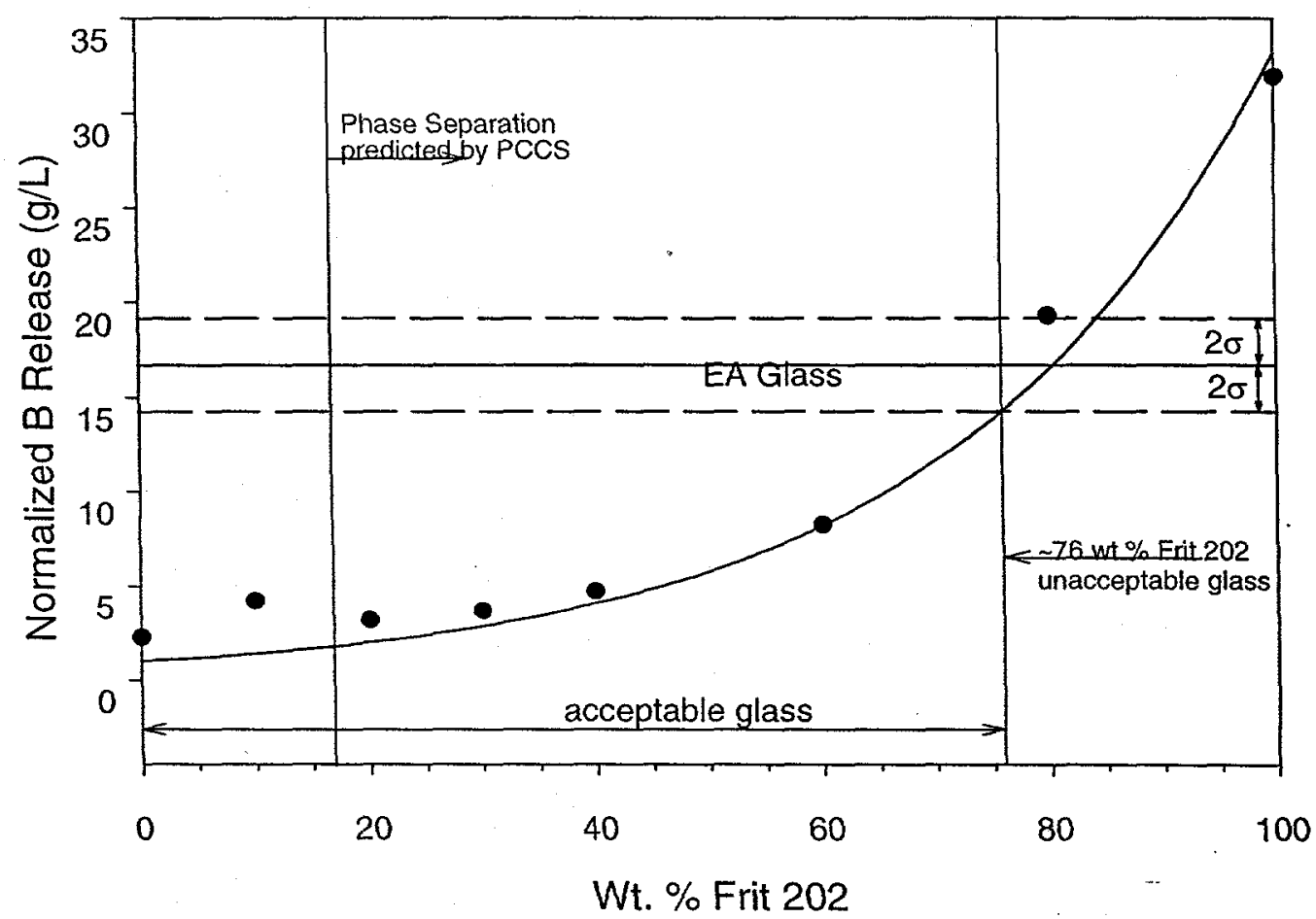

Figure 10. Boron release of Part 2 glasses as a function of Frit 202 additions. 


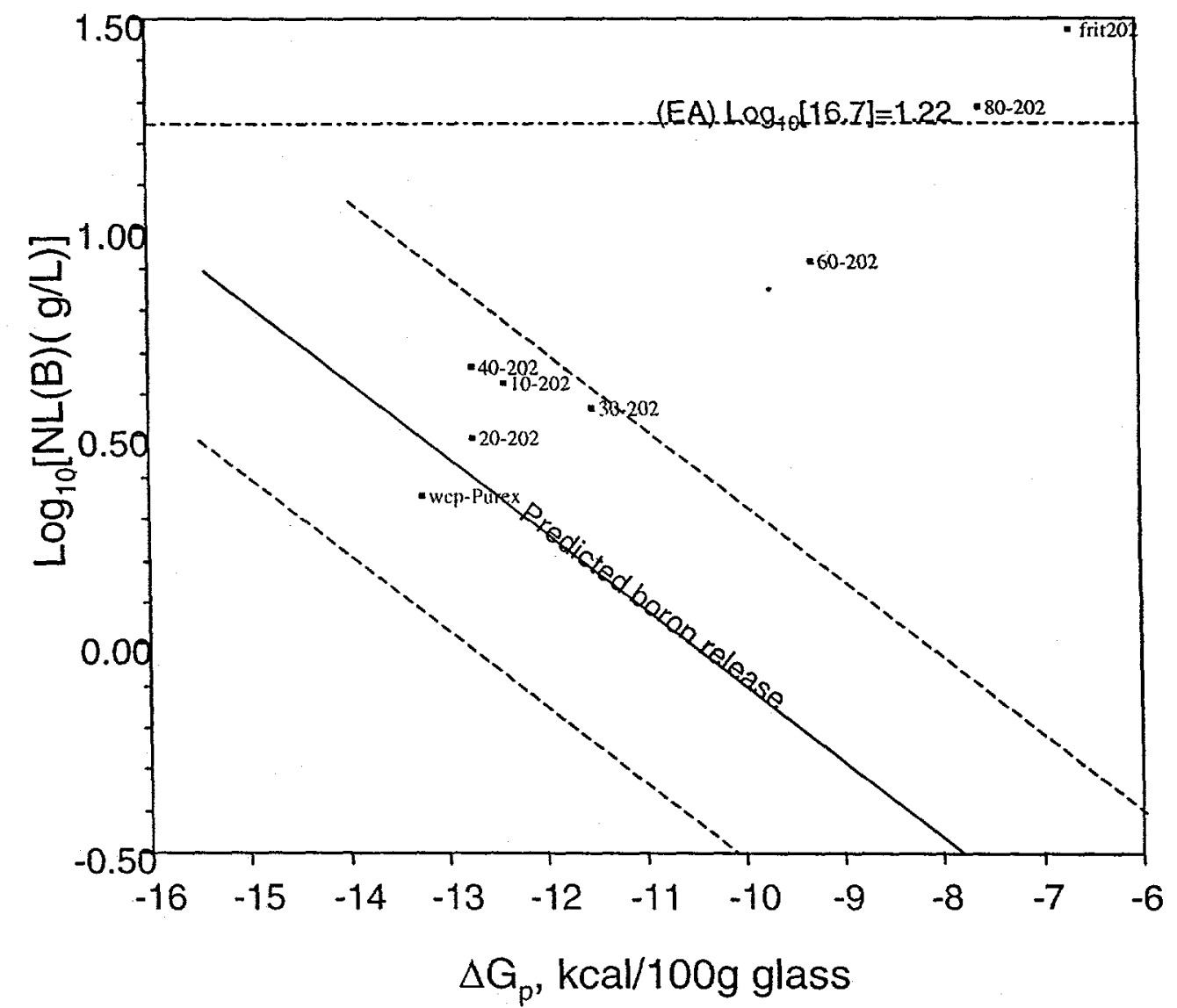

Figure 11. Log of the normalized boron release vs. the calculated free energy of hydration.

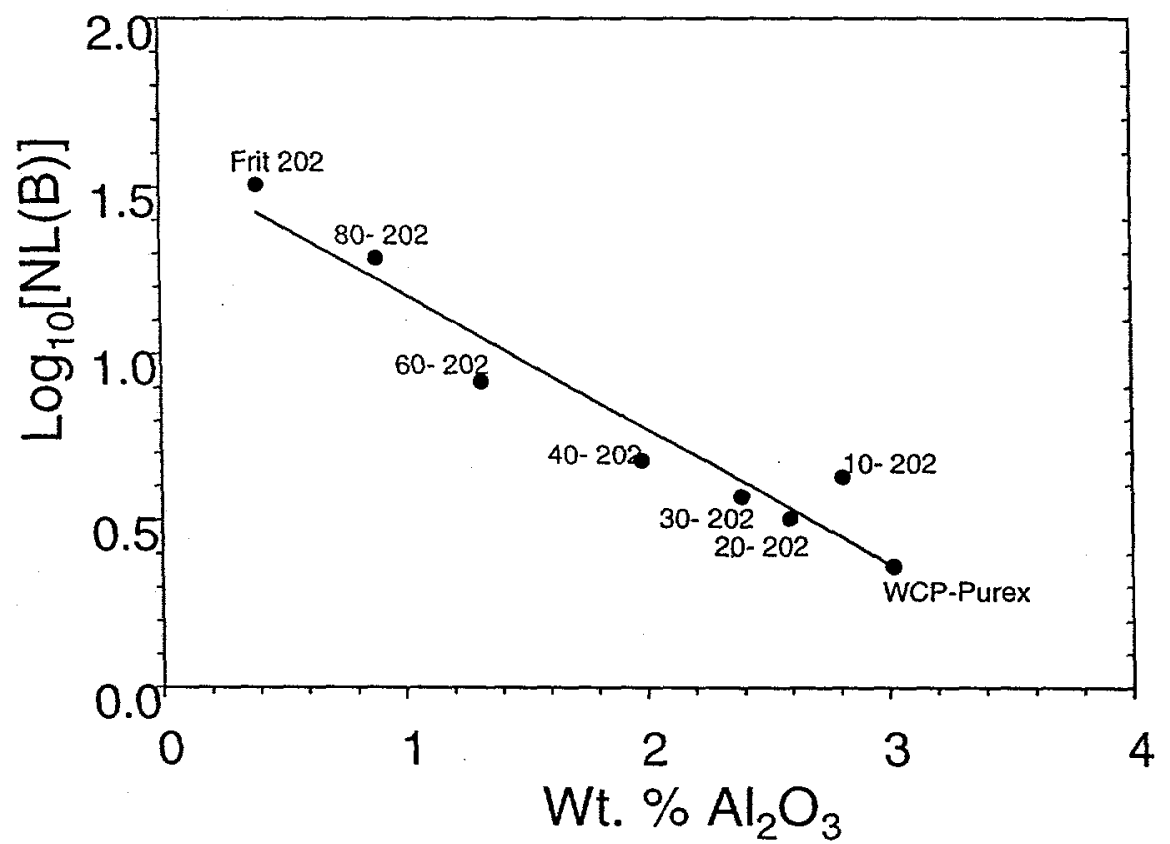

Figure 12. Log of the normalized boron release vs. the weight percent of alumina in the Part 2 glasses. 


\section{CONCLUSIONS}

\section{Part 1}

Based upon the glasses evaluated in this study, it cannot be stạted with certainty that alumina will suppress phase separation in all sodium borosilicate glasses. When alumina is added to phase separated glasses that exhibit an interconnected structure, Type A phase separation, it may reduce the scale of the phase separation, but the alumina does not necessarily eliminate phase separation. The continued presence of an interconnected, low durability phase would limit the effectiveness of alumina in increasing glass durability.

The addition of nominal amounts (3-5 wt. \%) of phosphorus induces phase separation in previously homogeneous, high-boron containing borosilicate glasses. The phosphorus causes a significant reduction in durability. Heat treatments do not significantly reduce the durability of phosphorus containing phase separated glasses. Results indicate that the silica-rich phase is contained in droplets dispersed in the alkali boron-rich phase. Heat treatment of these glasses does cause the crystallization of silica. Evidence suggests a Type B phase separation microstructure, leading to the reduction in durability through the formation of a less durable continuous phase.

\section{Part 2}

Frit 202 additions to WCP-Purex glass leads to a gradual decline is glass durability. The current phase separation discriminator is conservative in determining amorphous phase separation in these glasses. The conservative nature of the discriminator ensures that the DWPF cannot produce phase separated glasses. However, this current study corroborates previous work ${ }^{9}$ which suggested an opportunity to increase the operational window. This is based upon the gradual drop-off of measured durability as a glass composition changed incrementally from homogeneous to phase separated in the scale detectable by TEM. The glasses produced in this study indicate that amorphous phase separation predictions could be enhanced with additional glasses produced in this compositional region. There is also evidence that the prediction of glass durability from the free energy of hydration can be applicable to some glasses predicted by the discriminator to be phase separated. In homogeneous glasses, additions of alumina can significantly improve glass durability.

\section{RECOMMENDATIONS}

There is a need to evaluate the effects of the scale and type of phase separation on glass durability. The Part 1 glasses containing alumina appear to be homogeneous but the composition lies in a region of phase separation and the durability of the glasses did not improve with the addition of alumina. These glasses should be evaluated using alternate analytical tools that may detect phase separation on a smaller scale than can be observed using TEM. The glasses in Part 2 of this study should be heat-treated and evaluated using the PCT and TEM. These glasses as 
well as the quenched glasses produced in Part 2 and the alumina containing glasses in Part 1 should be evaluated for phase separation using other means (SANS/SAXS).

${ }^{1}$ M. Tomozawa, "Phase Separation in Glass, " in Treatise on Materials Science and Technology, Vol, 17, Eds. M. Tomozawa and R.H. Doremus, pp. 71-113, Academic Press, New York (1972).

${ }^{2}$ C.M. Jantzen, "Phosphate Additions to Borosilicate Waste Glass Cause Phase Separation," DPST-86-389 (1986).

${ }^{3}$ C.M. Jantzen, J.B. Pickett, K.G. Brown, T.B. Edwards, and D.C. Beam, "Process/Product Models for the Defense Waste Processing Facility (DWPF): Part 1. Predicting Glass Durability from Composition Using A $\underline{T H}$ ermodynamic $\underline{H}$ ydration $\underline{E}$ nergy $\underline{R}$ eaction $M O$ del (THERMO) (U) WSRC-TR-93-672, Rev.1(1993).

${ }^{4}$ D.K. Peeler and P.R. Hrma, "Compositional Range of Durable Borosilicate Simulated Waste Glasses," in Emerging Technologies in Hazardous Waste Management VI, eds. D.W. Tedder and F.G. Pohland, pp. 323-338, American Academy of Environmental Engineers (1996).

${ }^{5}$ W. Haller, D.H. Blackburn, F.E. Wagstaff and R.J. Charles, "Metastable Immiscibility Surface in the System $\mathrm{Na}_{2} \mathrm{O}-\mathrm{B}_{2} \mathrm{O}_{3}-\mathrm{SiO}_{2}$," J. Amer. Cer. Soc., Vol. 53 No. 1, pp. 34-38 (1970).

${ }^{6}$ M.B. Volf, Glass Science and Technology, 7: Chemical Approach to Glass, pp. 280-303, Elsevier, Amsterdam (1984).

${ }^{7}$ S.L. Marra, R.E. Edwards and C.M. Jantzen, "Thermal History and Crystallization Characteristics of the DWPF Glass Wasteform," Proceedings of the $3^{\text {rd }}$ International Conference on High Level Radioactive Waste Management Vol.1 pp. 917-924, American Nuclear Society, (1992).

${ }^{8}$ J.D. Vienna, P.R. Hrma, M.J. Schweiger, M.H. Langowski, P.E. Redgate, D.S. Kim, G.F. Peipel, D.E. Smith, C.Y. Chang, D.E. Rinehart, S.E. Palmer and H. Li, "Effect of Composition and Temperature on the Properties of HighLevel Waste Glass Melting Above $1200^{\circ} \mathrm{C}$," Draft, PNNL-10987, Pacific Northwest National Laboratory, Richland, WA, (1996).

${ }^{9}$ D.K. Peeler, Technical Status Report on the Prediction of Amorphous Phase Separation in multicomponent Borosilicate Glasses," WSRC-TR-97-00313, Rev. 0 (1997). 
Distribution

TFA

R.L. Gilchrist

T.M. Brouns

S.N. Schlahlta

G.C. Notch, 8

J.A. Frey

STI, 4

E.W. Holtzscheiter

DOE-SR

E.A. Korzun

K.L. Hooker

WSRC

E.W. Holtzscheiter

C.R. Goetzman

D.A. Crowley

L.F. Landon

C.T. Randall

J.R. Harbour

N.E. Bibler

D.F. Bickford

C.M. Jantzen

K.G. Brown

D.K. Peeler

R.F. Schumacher

M.E. Smith

J.R. Zamecnik

K.A. Howard 